\title{
Progress in Anti-Mammarenavirus Drug Development
}

\author{
Yu-Jin Kim ${ }^{1} \mathbb{D}$, Victor Venturini ${ }^{1,2} \mathbb{D}$ and Juan C. de la Torre ${ }^{1, *} \mathbb{C}$ \\ 1 Department of Immunology and Microbiology, The Scripps Research Institute, La Jolla, CA 92037, USA; \\ yujin@scripps.edu (Y.-J.K.); v.venturini@outlook.es (V.V.) \\ 2 Department of Biotechnology, Faculty of Experimental Sciences, Francisco de Vitoria University (UFV), \\ Carretera Pozuelo-Majadahonda, Km 1,800, Pozuelo de Alarcón, 28223 Madrid, Spain \\ * Correspondence: juanct@scripps.edu
}

Citation: Kim, Y.-J.; Venturini, V.; de la Torre, J.C. Progress in Anti-Mammarenavirus Drug Development. Viruses 2021, 13, 1187. https://doi.org/10.3390/v13071187

Academic Editor:

Luis Martinez-Sobrido

Received: 25 May 2021

Accepted: 19 June 2021

Published: 22 June 2021

Publisher's Note: MDPI stays neutral with regard to jurisdictional claims in published maps and institutional affiliations.

Copyright: (c) 2021 by the authors. Licensee MDPI, Basel, Switzerland. This article is an open access article distributed under the terms and conditions of the Creative Commons Attribution (CC BY) license (https:/ / creativecommons.org/licenses/by/ $4.0 /)$.

\begin{abstract}
Mammarenaviruses are prevalent pathogens distributed worldwide, and several strains cause severe cases of human infections with high morbidity and significant mortality. Currently, there is no FDA-approved antiviral drugs and vaccines against mammarenavirus and the potential treatment option is limited to an off-label use of ribavirin that shows only partial protective effect and associates with side effects. For the past few decades, extensive research has reported potential anti-mammarenaviral drugs and their mechanisms of action in host as well as vaccine candidates. This review describes current knowledge about mammarenavirus virology, progress of antiviral drug development, and technical strategies of drug screening.
\end{abstract}

Keywords: mammarenavirus; antiviral drug; drug repurposing; high-throughput screening

\section{Introduction}

Members of the family Arenaviridae are classified into four genera based on phylogenetic analysis of their RNA-directed RNA polymerase (L protein) and nucleoprotein (NP) sequences: Antennavirus, Hartmanivirus, Mammareanvirus, and Reptarenavirus [1]. Antennaviruses (2 species) were discovered in actinopterygian fish by next-generation sequencing, and no biological isolate has been reported yet. Hartmaniviruses (4 species) and reptarenaviruses (5 species) infect captive snakes, and some of them have been associated with boid inclusion body disease (BIBD). Mammarenaviruses (39 species) infect mainly rodents, and the infection is generally asymptomatic. Current knowledge about the biology of snake and fish arenaviruses is very limited, and their zoonotic potential unknown. In contrast, some mammarenaviruses have been found to infect and cause disease in humans.

Mammarenaviruses are enveloped viruses with a bi-segmented single-stranded negativesense RNA genome [1]. Mammarenaviruses cause chronic infections of their rodent natural reservoirs across the world, but some of them have zoonotic potential. Human infections occur through mucosal exposure to aerosols or by direct contact of abraded skin with infectious materials [2]. Based on their antigenic properties, mammarenaviruses have been classified into two distinct groups, Old world (OW) mammarenaviruses, aka Lassa-lymphocytic choriomeningitis virus serocomplex," including viruses present in Africa and the worldwide distributed lymphocytic choriomeningitis virus (LCMV), and the New World (NW) mammarenaviruses, aka "Tacaribe serocomplex", including viruses indigenous to the Americas [3]. Both OW and NW mammarenaviruses include several species members that can cause severe hemorrhagic fever (HF) diseases in humans that are associated with high morbidity and significant mortality; these viruses include Lassa (LASV), Junin (JUNV), Machupo (MACV), Guanarito (GTOV), Sabia (SABV), Chapare (CHPV), and Lujo (LUJV) [4]. Concerns posed by human pathogenic mammarenaviruses are exacerbated by the overall lack of FDA-licensed vaccines and current anti-mammareanavirus therapy being limited to off-label use of ribavirin that is only partially effective, has a narrow therapeutic window, and can be associated with side effects [5]. The only mammarenavirus vaccine tested in humans is the live-attenuated Candid\#1 strain of 
JUNV that has been shown to be safe and provide effective protection against Argentine HF (AHF) disease caused by JUNV [6,7]. Accordingly, Candid\#1 is approved in Argentina for use in populations at high risk of JUNV infection [8].

This article presents a concise review of our current understanding of the mammarenavirus life cycle at the molecular and cellular level and of progress on antiviral drugs targeting specific steps of the mammarenavirus life cycle and their implications for potential therapeutic strategies against human pathogenic mammarenaviruses.

\section{Mammarenavirus Molecular and Cell Biology}

\subsection{Virus Particle, Viral Proteins and Genomic Organization}

Mammarenavirus virions are spherical lipid-enveloped particles with a wide diameter range (400 to $2000 \AA$ ) that enclose the bi-segmented negative-stranded (NS) RNA viral genome [9]. Each genome segment, L and S, uses an ambisense coding strategy to direct the synthesis of two polypeptides [10]. The small (S, ca $3.5 \mathrm{~kb}$ ) genome segment encodes the viral nucleoprotein (NP) and the glycoprotein precursor GPC that, upon co-and posttranslational processing, generates the GP complex that forms the spikes present at the virion surface and that mediate virus cell entry. The large $(\mathrm{L}, \mathrm{ca} 7.5 \mathrm{~kb})$ genome segment encodes the viral RNA-dependent RNA polymerase (RdRp; L protein) and the small RING finger protein $Z$ that is a bona fide matrix protein (Figure 1A). NP is the most abundant viral protein in infected cells and virions. NP encapsidates the virus genome and antigenome RNA species to form a nucleocapsid complex that, in association with the viral L polymerase, forms the viral ribonucleoprotein complex (vRNP) that directs the biosynthetic processes of replication and transcription of the viral genome [11]. NP has also been shown to counteract the induction of type I interferon (IFN-I) response that plays a critical role in the cell innate immune response to infection [10,12-14]. This anti-IFN-I activity of NP has been linked to a functional DEDDh $3^{\prime}-5^{\prime}$ exoribonuclease domain present within the NP C-terminal region $[15,16]$. GPC is co-translationally cleaved by cellular signal peptidases to generate a 58 amino acid-long stable signal peptide (SSP) and the GP1/2 precursor that is post-translationally processed by the cellular protease subtilisin kexin isozyme-1 (SKI-1)/site 1 protease (S1P) to generate the mature virion surface glycoproteins GP1 and GP2 [17]. The SSP, together with GP1 and GP2, form the spikes (GP complex) located at the surface of mature virions and that mediate virus cell entry. The GP1 subunit is located at the top of the spike away from the membrane and mediates virion interaction with host cell-surface receptors [18,19]. The GP2 subunit is involved in virion-cell membrane fusion by means of a conformational change triggered by the acidic environment of the endosome $[20,21]$. The SSP has been implicated in the trafficking and processing of the viral envelope glycoproteins and in the GP2-mediated $\mathrm{pH}$-dependent fusion process [3]. N-glycosylation modifications of GPC are required for SKI-1/S1P cleavage [22], whereas SSP must be myristoylated for the GP2-mediated fusion activity [23]. The L protein mediates replication and transcription of the virus RNA genome by the vRNP. The L protein also has an endonuclease activity that mediates the cap-snatching process required for transcription initiation [11,24]. The RING finger protein $\mathrm{Z}$ serves as a bona fide matrix protein [25]. $\mathrm{Z}$ has been shown to interact with various host cell proteins, including the eukaryote translation initiation factor $4 \mathrm{E}$ (eIF4E) and the promyelocytic leukemia protein (PML), interactions that might contribute to facilitate virus multiplication [26-30]. As with other matrix proteins of NS RNA viruses, $Z$ also negatively regulates the activity of the virus polymerase [31,32], mediates interactions between the vRNP and GP2 required for assembly of matured viral particles [33,34], and is the main driving force of viral budding from the plasma membrane, a process that includes Z's interaction with several members of the endosomal sorting complex required for transport (ESCRT) $[25,35]$. $Z$ has also been shown to interact with the cytosolic pathogen recognition receptor (PRR) RIG-I and counteracts the induction of the IFN-I response. 
A

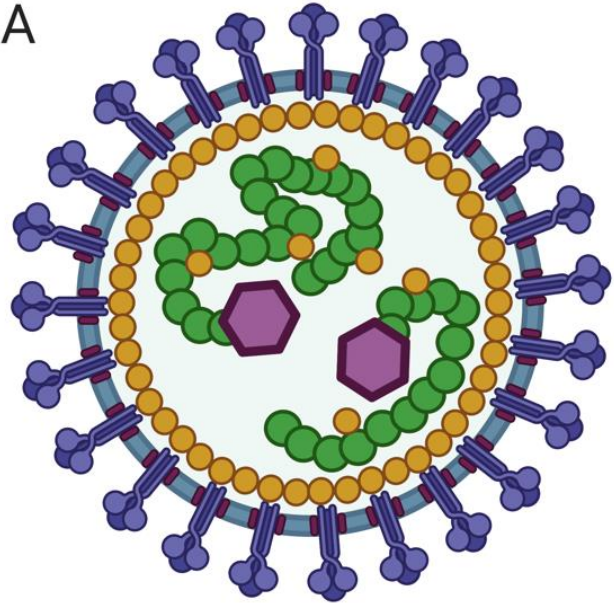

Figure 1. Mammarenavirus virion and genome organization. (A) Schematic diagram of mammarenavirus virion. The virion is enveloped and contains four types of viral proteins; glycoprotein (GP), nucleoprotein (NP), RdRp (L), the RING finger protein Z. (B) Genome organization of mammarenaviruses. The bi-segmented negative sense RNA genome consists of the large (L) and small (S) segments. This ambisense genome organization encodes two independent viral proteins in each segment; GPC and NP in the S segment, $\mathrm{Z}$ and $\mathrm{L}$ in the $\mathrm{L}$ segment.

Both genome segments contain non-coding cis-regulatory elements required for replication and transcription of the virus genome, including the $5^{\prime}$ and $3^{\prime}$ untranslated regions (UTR) present at the ends of both RNA segments and the non-coding intergenic regions (IGR) separating the two open reading frames present in each genome segment [36]. Mammarenaviruses have highly conserved sequences at the $3^{\prime}$-end of the L and S RNA genome segments that contain the genome promoter recognized by the virus polymerase to initiate RNA synthesis [37]. Genomes and antigenome RNAs are highly complementary between their $5^{\prime}$ - and $3^{\prime}$-termini, with both $\mathrm{L}$ and $\mathrm{S}$ genome segments, predicted to form panhandle structures, which is consistent with EM images showing the existence of circular RNP complexes within mammarenavirions. Mammarenavirus IGRs are predicted to fold into stable hairpin structures that constitute bona fide transcription termination signals. There are significant differences in sequence and predicted folded structure between the $S$ and $L$ IGR, but among isolates and strains of the same arenavirus, the $S$ and L IGR sequences are highly conserved. The IGR has been also implicated in virus assembly or budding, or both, being required for the generation of infectious particles [38,39].

\subsection{Mammarenavirus Life Cycle \\ 2.2.1. Cell Entry}

Mammarenavirus enter susceptible cells mainly via receptor-mediated endocytosis. The acidic environment of the late endosome facilitates a $\mathrm{pH}$-dependent conformational change in the GP complex that induces a GP2-mediated fusion step between viral and cell membranes. Following fusion, the viral RNP is released into the cytoplasm, where it directs both replication and transcription of the viral genome (Figure 2). Different cell surface receptors are used by Old World (OW) and New World (NW) mammarenaviruses. OW mammarenaviruses, including lymphocytic choriomeningitis virus (LCMV) and Lassa virus (LASV), as well as clade C NW mammarenaviruses, use $\alpha$-dystroglycan as the major high-affinity receptor to which GP1 attaches $[40,41]$. In contrast, pathogenic clade B NW mammarenaviruses including Guanarito (GTOV), Sabia (SABV), Junin (JUNV), Machupo $(\mathrm{MACV})$ viruses use human transferrin receptor 1 (hTfR1) as the main receptor for entry [42]. A cell entry receptor for clade A NW mammarenaviruses has not been identified yet [43]. The OW hemorrhagic fever mammarenavirus Lujo virus (LUJV) LUJV was shown to use neuropilin (NRP)-2 as its main cell entry receptor [44]. Interestingly, NRP-2 is highly expressed on microvascular endothelial cells and alveolar macrophages, which may explain the extent of coagulopathy observed in LUJV-induced clinical disease and 
aerosol transmission of LUJV [45-47]. Once GP1 binds to the cellular receptor, the virion is endocytosed following different pathways by NW and OW mammarenaviruses. NW mammarenaviruses are internalized via clathrin-dependent endocytosis $[48,49]$, whereas OW arenaviruses proceed through a clathrin-independent pathway that involves PI3Kmediated formation of multivesicular bodies (MVB) during late endocytosis and the endosomal sorting complex required for transport (ESCRT) proteins [50]. Notably, completion of the cell entry process for LASV and LUJV requires a late endosomal receptor switch mechanism. For LASV, the lysosome-associated membrane protein 1 (LAMP1) mediates a cholesterol-dependent $\mathrm{pH}$-receptor switch mechanism [51], which stimulates GP1 dissociation from the GP complex and a conformational change in GP2 that drives the fusion of viral and cell membranes [20,52]. In the case of LUJV, this process is mediated by the tetraspanin CD63 [44].

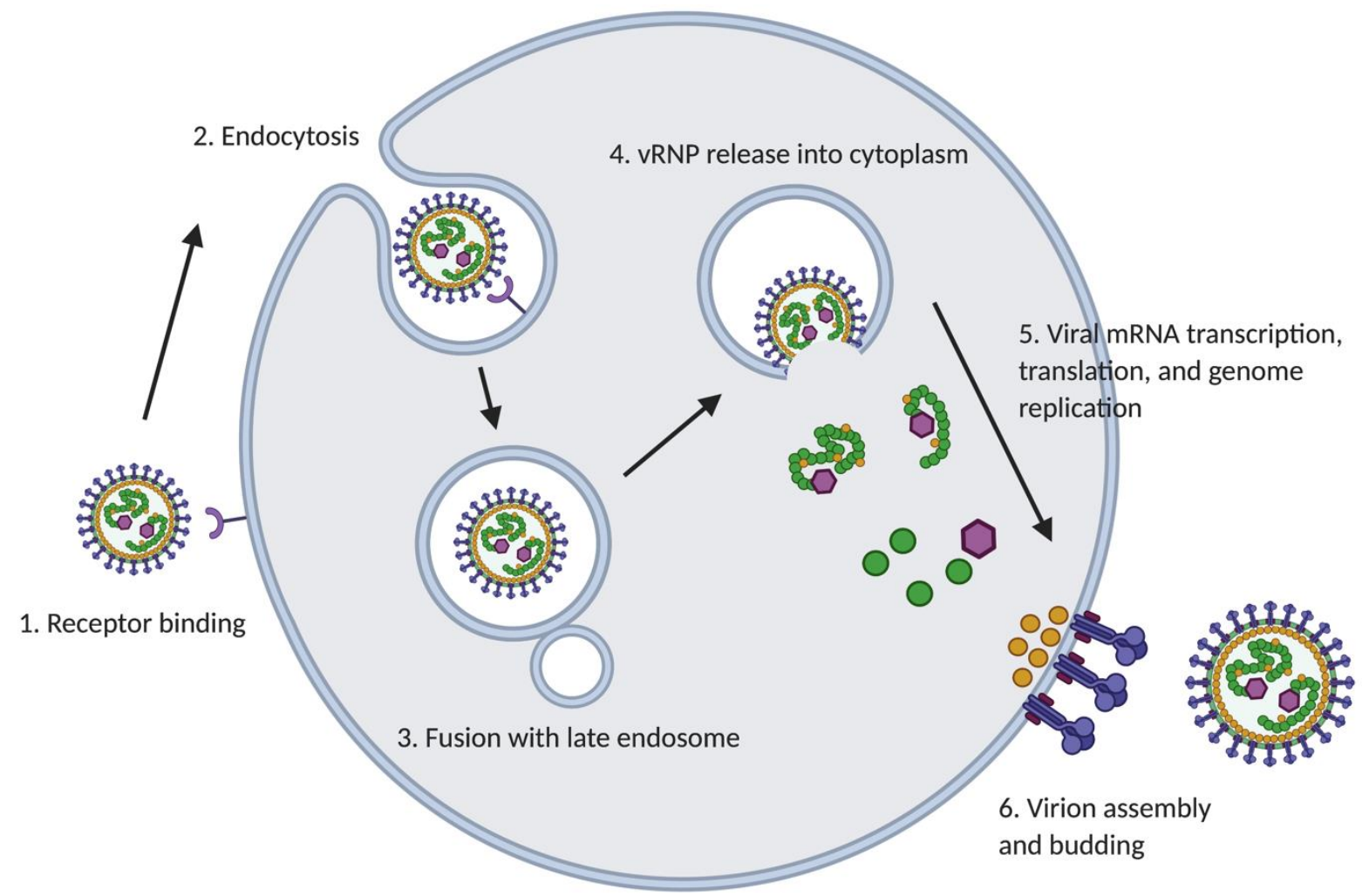

Figure 2. Mammarenavirus life cycle. Virus cell entry is initiated by the interaction between GP and different receptors present at the cell surface (1). Virus uptake into the cell is mediated by endocytosis (2). The acidic environment of the late endosome promotes fusion between viral and host cell membranes (3). Following the pH-dependent membrane fusion event, the vRNP is released into the cytoplasm, where it directs the biosynthetic processes of replication and transcription of the viral genome $(4,5)$. Viral assembly takes place in the cell cytoplasm, and virions bud from the plasma membrane. $\mathrm{Z}$ plays critical roles in both these processes (6).

\subsubsection{Genome Replication and Transcription}

Following its release from the late endosome into the cytoplasm, the vRNP directs the biosynthetic processes of replication and transcription of the viral genome RNAs (Figure 2). L and NP are the minimal viral trans-acting factors required for these processes [53,54], whereas $Z$ has been shown to exhibit a dose-dependent inhibitory effect on the vRNP activity, likely by interacting with the viral L polymerase and disabling its catalytic activity [31,53].

Mammarenaviruses generate three different RNA species during replication and transcription: genomic (gRNA) and antigenomic (agRNA) RNA species and sub-genomic viral mRNA species. Synthesis of viral mRNAs starts at the genome promoter and terminates 
within the distal region of the hairpin-structured IGRs [4]. Due to the ambisense coding strategy that characterizes mammarenavirus genome, NP and L mRNAs are transcribed from the genomic RNA, while GPC and Z mRNAs are transcribed from the corresponding antigenome RNA species. This ambisense coding strategy has been suggested to produce a hierarchal pattern of gene expression where NP and L proteins are produced at very early times of infection, and GPC and Z proteins at later times [4,55].

Mutation-function analysis using cell-based minireplicon assays for several mammarenaviruses indicated that the activity of the mammarenavirus genomic promoter requires both sequence specificity within the highly conserved $3^{\prime}$-terminal 19 nucleotides of arenavirus genomes and the integrity of the predicted panhandle structure formed via sequence complementarity between the $5^{\prime}$ - and $3^{\prime}$-termini of viral genome RNAs $[37,56]$. IGRs serve as bona fide transcription termination signals, but the synthesis of translationcompetent viral mRNAs does not strictly require the presence of the IGR $[38,39,57]$.

Mammarenavirus transcription initiation uses a cap-snatching mechanism, where short $5^{\prime}$-capped primers derived from host-cell mRNAs are used by the virus polymerase complex to prime the synthesis of viral mRNAs $[4,58]$. The $5^{\prime}$-capped primers are generated via cleavage of cellular mRNAs by the endonuclease activity associated with the N-terminus of L [59]. The 5 '-end of mammarenavirus genome and antigenome RNAs each contain a non-templated G residue that likely reflects a prime-and-realign mechanism for RNA replication mediated by L [60,61]. Mammarenavirus genome and antigenome, sequence terminal complementarity combined with the prime-and-realign mechanism for replication initiation generates doublestranded RNAs with overhanging $5^{\prime}$-ppp nucleotides. These structures can act as RIGI decoys, thereby diminishing RIG-I-mediated interferon induction in mammarenavirusinfected cells [62]. NP mRNA of the NW mammarenavirus Tacaribe (TCRV) was detected at early times of infection and in the presence of inhibitors of protein synthesis, suggesting that, unlike the closely related bunyaviruses, but similarly to orthomyxoviruses, rhabdoviruses, and paramyxoviruses, primary transcription directed by the incoming mammarenavirus vRNP can proceed in the absence of translation $[4,63]$.

\subsubsection{Assembly and Budding}

As with many other enveloped NS RNA viruses, mammarenavirus assembly and budding require the participation of the matrix protein $Z$ [64]. Z interacts with GP2 [33] and NP [65], which facilitates vRNP-GP complex interactions required for the assembly of mature viral particles (Figure 2). As with other matrix proteins, $Z$ has the capability to selfassemble and direct budding of VLPs [35]. Z budding activity is driven by canonical viral late (L) domains within the C-terminus of $Z$, which mediate $Z$ interaction with components of the cellular ESCRT complexes [66] known to play essentials roles in the budding process of different viruses $[67,68]$.

\section{Drugs Targeting Different Steps of Mammarenavirus Life Cycle}

\subsection{Cell Entry}

Completion of mammarenavirus cell entry requires a GP2-mediated fusion event between viral and cellular membranes, a process triggered by the acidic environment of the late endosome. Therefore, targeting the GP2-mediated fusion event is an attractive strategy to inhibit mammarenavirus infection. Accordingly, a high-throughput screen (HTS) of a small molecule library identified a series of molecules (ST-193, ST-294, and ST-336) that target GP2 and inhibit viral entry $[69,70]$. ST-193 has been shown to confer significant protection against LASV infection in a guinea pig model [71], and the optimized chemical analog of ST-193 compound, LHF-535, was shown to be a potent broad-spectrum inhibitor of HF mammarenaviruses via targeting the GP2-mediated fusion step of virus cell entry [72]. Another GP2-mediated fusion inhibitor, F3406, was shown to inhibit LCMV multiplication [73]. AVP-p, a peptide derived from the Pichinde virus (PICV) GP2 subunit, was found to bind the prefusion state of the GP complex, which arrests the GP2-mediated fusion event [74]. Arbidol (umifenovir) was developed as an inhibitor of influenza virus 
infection, but it has been shown to exhibit broad-spectrum antiviral activity against different viruses by interfering with different steps, including cell entry of the virus life cycle [75]. Arbidol inhibits both LASV and Ebola virus (EBOV) GP-mediated fusion events required to complete the virus cell entry process $[76,77]$. Screening of a natural product library identified tangeretin as a cell entry inhibitor of seven different HF-causing viruses [78].

Several compounds have been shown to inhibit mammarenavirus cell entry via offtarget activities distinct from their intended therapeutic effects. The clotrimazole-derivative TRAM-34 is an ion channel blocker that antagonizes the calcium-activated potassium channel KCa3.1. TRAM-34 specifically inhibited mammarenavirus GP2-mediated fusion, and this anti-mammarenaviral effect was independent of its channel blocking activity [79]. Losmapimod, an p38 MAPK inhibitor, was developed as a therapeutic drug for chronic obstructive pulmonary disease (COPD) and has been reported to inhibit LASV entry by blocking the $\mathrm{pH}$-dependent GP2-mediated fusion without requiring inhibition of p38 MAPK [80]. NH125, a selective eEF-2 kinase inhibitor, inhibited cell entry of recombinant VSVs expressing envelope glycoproteins of avian influenza virus, EBOV, and LASV due to the compound lysosomotropic properties and independently of eEF-2 kinase inhibition [81]. ZCL278 was identified as an inhibitor of Cdc42, a small GTPase that regulates actin polymerization [82]. Subsequently, ZCL278 was shown to exhibit broad-spectrum anti-viral activity, including against mammarenaviruses, by redistributing viral particles from endosomal to lysosomal membranes, and this antiviral activity was not dependent on the downregulation of Cdc42 activity [83]. The antifungal drug isavuconazole, which was approved by the FDA as an orphan drug for aspergillosis, mucormycosis, and candidiasis, was shown to inhibit viral fusion, targeting the SSP-GP2 interface of LASV [84]. The adamantyl diphenyl piperazine 3.3 was developed to target the lysosome-associated membrane protein 1 (LAMP1) by competing with cholesterol, preventing the interaction between LAMP1 and LASV GP [85].

\subsection{Viral Genome Replication}

The nucleoside analog ribavirin has been shown to inhibit mammarenavirus replication in cell culture systems, as well as to have clinical benefits when used to treat LF cases at early times after the onset of clinical symptoms [86,87]. Several different mechanisms of action have been proposed to account for the antiviral activity of ribavirin, including up-regulation of interferon responses [88], GTP pool depletion by inhibiting IMP dehydrogenase (IMPDH), and direct inhibition of viral RNA-directed RNA polymerase (RdRp) activity [89]. Due to its broad-spectrum antiviral activity against multiple RNA and DNA viruses, most likely different mechanisms of action, and combination of them, contribute to the antiviral activity of ribavirin. Notably, a recent study has shown that the main mechanism of the antiviral activity of ribavirin against LASV, is by protecting LASV-infected cells from death [90].

Favipiravir was initially developed as an antiviral drug targeting the influenza virus polymerase and subsequently shown to exhibit a broad-spectrum activity against different RNA viruses, including mammarenaviruses, bunyaviruses, flaviviruses, alphaviruses, picornaviruses, and noroviruses [91,92]. BCX4430 is another broad-spectrum inhibitor of many types of RNA viruses, including mammarenaviruses, which interferes with the activity of the viral RdRp by acting as an RNA chain terminator [93].

Peptide-conjugated phosphorodiamidate morpholino oligomers (PPMO), designed to target conserved regions within mammarenavirus genome RNA, were effective against multiple mammarenaviruses, including JUNV, LCMV, TCRV, and PICV [94]. The inhibitors of DEDDh family of $3^{\prime}-5^{\prime}$ exonucleases aurintricarboxylic acid (ATA) and pontacyl violet $6 \mathrm{R}$ (PV6R) have been reported to inhibit the $3^{\prime}-5^{\prime}$ exonuclease activity of LASV NP [15], which in addition to its role counteracting the host cell IFN-I response, has been shown to play a critical role in viral fitness in IFN-I deficient cells [95]. As metal-chelating pharmacophores, diketo acids, polyphenols, and $N$-hydroxyisoquinoline-1,3-diones were able to inhibit the endonuclease activity of arenavirus L protein, which resulted in inhibition of the capsnatching mechanism used by mammarenavirus polymerases to initiate transcription of 
viral mRNAs [96]. A carboxamide-derivatized disulfide, NSC4492, was reported to show antiviral activity against JUNV and TCRV [97] and this compound was shown to impair viral RNA synthesis of JUNV via targeting the replication complex [98]. KP-146 was shown to have dual roles in its antiviral activity against LCMV, not only interfering with vRNP activity responsible for directing LCMV genome replication and gene transcription but also inhibiting $\mathrm{Z}$ protein-mediated budding process [95].

\subsection{Processing of GPC}

The mammarenavirus GPC precursor is co-translationally cleaved by cellular signal peptidases to generate a 58 amino acid-long stable signal peptide (SSP) and the immature GP1/GP2 precursor [99]. Subsequent processing of GP1/GP2 by the cellular subtilisin kexin isozyme-1 (SKI-1)/ site-1 protease (S1P) into GP1 and GP2 is required for the production of infectious progeny $[17,19]$. GP1, GP2, and the SSP form the mature trimeric GP spike complex [99]. Decanoyl-RRLL-chloromethylketone (dec-RRLL-CMK) was developed as a SKI-1/S1P inhibitor based on the cleavage recognition site present within LASV GPC [100] and was shown to exert a potent antiviral activity against LCMV as well as additive antiviral drug activity in combination with ribavirin [101]. PF-429242, a small molecule inhibitor of S1P, was shown to interfere with the proteolytic processing of GPC, which correlated with the compound's ability of inhibiting multiplication of LCMV and LASV in cultured cells [102]. In S1P-deficient cells, wild-type LCMV consistently underwent extinction without emergence of S1P-independent escape variants [101]. Moreover, PF429242 efficiently and rapidly cleared persistent virus from infected cells, and interruption of drug treatment did not result in re-emergence of infection, indicating that PF-429242 treatment resulted in virus extinction [103]. These findings indicate a high genetic barrier for the emergence of viral variants capable of using an alternative host cellular protease for the processing of GPC, thus making S1P a very attractive target for the development of antiviral drugs against mammarenaviruses.

\subsection{Virion Assembly and Cell Egress}

Assembly and cell release of infectious mammarenavirus progeny involves Z-L, Z-NP, and Z-GP interactions to facilitate the co-localization of all viral proteins for the assembly of mature infectious particles [30]. Functional studies have shown that the matrix $Z$ protein plays a key role in mammareanvirus budding, a process mediated by the interaction of $Z$ late (L) domain motifs, PTAP and PPPY, with components of the cellular ESCRT complexes [104]. $Z$-mediated budding also requires myristoylation of the $Z$ protein at a glycine $(G)$ in position 2 to target $Z$ to the plasma membrane, the location of arenavirus budding [105]. Accordingly, treatment with 2-hydroxymyristic acid, an inhibitor of the N-myristoyltransferase (NMT), impaired $\mathrm{Z}$ budding activity and production of mammarenavirus infectious progeny [105]. Valproic acid (VPA), a short-chain fatty acid, used in anti-epileptic therapy [106], was shown to inhibit Z-mediated budding of LCMV, likely due to VPA-mediated alteration of the lipid composition of cellular membranes, which is critical in virus budding [107]. Compound 0013, identified as a potent inhibitor of the interaction between the PTAP L domain and Tsg101, a member of the host cell ESCRT complex proteins, was shown to inhibit viral budding by blocking the Z-Tsg101 interaction [108]. The ubiquitin ligase Nedd4 E3 is also a component of the ESCRT complex [109]. A small molecule termed compound1 was identified as an inhibitor of Z-Nedd4 interaction, resulting in inhibition of viral budding [110]. BEZ-235, a phosphatidylinositol 3-kinase (PI3K) inhibitor, was shown to inhibit $Z$ protein-mediated budding of LCMV and LASV by a mechanism of action yet to be determined [111]. In addition to driving virion assembly and release, $\mathrm{Z}$ proteins have been reported to modulate various host mechanisms such as repression of translation by binding and counteracting eIF4E [26] and suppression of host innate immune responses [112], suggesting potential host targets for developing antiviral drugs. Recent $Z$ interactome study has identified human proteins that interact with arenavirus $Z$ and validated potential host targets for antiviral therapeutics, including ADP ribosylation factor 1 (ARF1), ATP synthase, $\mathrm{H}$ transporting mitochondrial $\mathrm{F} 1$ 
complex beta polypeptide (ATP5B), ATPase $\mathrm{H}$ transporting lysosomal $38-\mathrm{kDa}$ V0 subunit $\mathrm{d} 1$ (ATP6V0D1), inosine monophosphate dehydrogenase 2 (IMPDH2), peroxiredoxin 3 (PRDX3), and Ras-related protein Rab5c [113].

\subsection{Monoclonal Antibodies}

Monoclonal antibody-based therapies represent an attractive strategy to treat infections by highly pathogenic mammarenaviruses. A monoclonal antibody specific for human transferrin receptor 1 (hTfR1), the receptor used by pathogenic NW mammarenaviruses, inhibits viral entry of several NW mammarenaviruses, including JUNV, GTOV, CHAV, SABV, and MACV [114]. In addition, monoclonal antibodies targeting mammarenavirus GP have been reported to have potent neutralizing activity against MACV and LASV that correlated with inhibition of virus multiplication $[115,116]$. A recent study documented the isolation of human monoclonal antibodies from LF survivors and characterized their epitope and neutralization profiles, showing that $80 \%$ of the monoclonal antibodies with neutralizing activity targeted complex epitopes involving LASV GP1 and GP2 subunits [117]. Importantly, this study identified several human monoclonal antibodies with neutralizing activities against members of the main four lineages of LASV, and some of them showed cross-reactivity to LCMV, LUJO, and MACV. This finding has provided insights to develop therapeutic strategies based on the use of broadly reactive monoclonal antibodies.

\subsection{Targeting Host Factors}

As strict parasites, viruses rely on many host cell factors to complete their life cycles. Therefore, there is increasing interest in targeting host cell factors required for virus multiplication as an antiviral drug strategy. Direct-acting antivirals (DAAs) that target specific viral gene products and functions are likely to be well tolerated by the infected host cell. Still, they are limited by the common problem in antiviral therapy posed by the emergence of drug-resistant variants. In contrast, the emergence of viral variants resistant to host-targeting antivirals (HTAs) is usually significantly reduced or entirely absent, but HTAs can be associated with significant side effects. However, side effects associated with the use of HTAs might be manageable in the case of acute infections, such as HF disease caused by arenaviruses, where the duration of the treatment would be rather short.

Dihydroorotate dehydrogenase (DHODH) small molecule inhibitors A3 and A77172 interfere with de novo pyrimidine biosynthesis and exhibit potent antiviral activity against LCMV and JUNV [118,119]. Likewise, de novo purine biosynthesis is a potential cellular target for the development of HTAs. Inhibition of inosine monophosphate dehydrogenase (IMPDH), a key enzyme in the purine biosynthesis pathway, was shown to be associated with a broad-spectrum antiviral activity against RNA viruses including JUNV [120,121]. S-adenosylhomocysteine hydrolase (SAHH) is an important cellular enzyme for regulating viral mRNA capped structures, and inhibition of SAHH activity by 3-deazaneplanocin was associated with potent antiviral activity against TCRV and PICV [122]. ATPase $\mathrm{Na}+/ \mathrm{K}+$ transporting subunit alpha 1 (ATP1A1) and prohibitin (PHB) were identified as mammarenavirus NP-interacting host cell proteins and act as pro-viral factors that promote mammarenavirus multiplication. Accordingly, the ATP1A1 inhibitors, ouabain and bufalin, as well as the PHB inhibitor, rocaglamide A, exhibit potent antiviral activity against LCMV and LASV infection [123].

Anti-mammarenaviral drugs discussed in this section have been summarized in Table 1. 
Table 1. Drugs with anti-mammarenaviral activity.

\begin{tabular}{|c|c|c|}
\hline Target & Drug Name & Mechanism \\
\hline & $\begin{array}{c}\text { ST-193 } \\
\text { ST-294 } \\
\text { ST-336 } \\
\text { LHF-535 } \\
\text { F3406 } \\
\text { AVP-p } \\
\text { arbidol } \\
\text { tangeretin }\end{array}$ & $\begin{array}{ll}\text { - } & \text { GP2 targeting compounds } \\
\text { - } & \text { Inhibition of } \mathrm{pH} \text {-dependent membrane fusion }\end{array}$ \\
\hline & TRAM-34 & $\begin{array}{ll}\text { - } & \text { Calcium-activated potassium channel blocker } \\
\text { - } & \text { Inhibition of } \mathrm{pH} \text {-dependent membrane fusion }\end{array}$ \\
\hline & losmapimod & $\begin{array}{ll}\text { - } & \text { p38 MAPK inhibitor } \\
\text { - } & \text { Inhibition of pH-dependent membrane fusion in p38 } \\
& \text { MAPK down regulation-independent manner }\end{array}$ \\
\hline \multirow[t]{5}{*}{ Viral entry } & NH125 & $\begin{array}{l}\text { - } \quad \text { eEF-2 kinase inhibitor } \\
\text { GP-mediated fusion inhibition due to } \\
\text { lysosomotropic properies }\end{array}$ \\
\hline & ZCL278 & $\begin{array}{ll}\text { - } & \text { Cdc42 inhibitor } \\
\text { - } & \text { Fusion inhibition by redistributing viral particles from } \\
\text { endosomal to lysosomal membranes }\end{array}$ \\
\hline & isavuconazole & $\begin{array}{l}\text { - } \quad \text { Antifungal drug for aspergillosis } \\
\text { - } \quad \text { Inhibition of pH-dependent membrane fusion by } \\
\text { targeting the SSP-GP2 interface }\end{array}$ \\
\hline & $\begin{array}{l}\text { dec-RRLL-CMK } \\
\text { PF-429242 }\end{array}$ & $\begin{array}{l}\text { - Blocking the proteolytic processing of GPC by inhibition } \\
\text { of host protease S1P }\end{array}$ \\
\hline & adamantyl diphenyl piperazine 3.3 & $\begin{array}{l}\text { - } \quad \text { Blocking the interaction between host LAMP1 and } \\
\text { viral GP }\end{array}$ \\
\hline
\end{tabular}


Table 1. Conts.

\begin{tabular}{|c|c|c|}
\hline Target & Drug Name & Mechanism \\
\hline \multirow{11}{*}{$\begin{array}{l}\text { Viral } \\
\text { genomereplication }\end{array}$} & ribavirin & $\begin{array}{ll}\text { - } & \text { Upregulation of host IFN responses } \\
\text { - } & \text { Cellular GTP depletion } \\
\text { - } & \text { Viral RdRp inhibition }\end{array}$ \\
\hline & $\begin{array}{l}\text { favipiravir } \\
\text { BCX4430 }\end{array}$ & - $\quad$ Viral RdRp inhibition \\
\hline & PPMO & - $\quad$ Interfering with viral RNA synthesis and translation \\
\hline & $\begin{array}{c}\text { ATA } \\
\text { PV6R }\end{array}$ & - $\quad$ Inhibition of NP exonuclease activity \\
\hline & $\begin{array}{c}\text { diketo acids } \\
\text { polyphenols } \\
\text { N-hydroxyisoquinoline-1,3-diones }\end{array}$ & - Inhibition of L endonuclease activity \\
\hline & $\begin{array}{l}\text { NSC4492 } \\
\text { KP-146 }\end{array}$ & - $\quad$ Targeting the vRNP to impair viral RNA synthesis \\
\hline & $\begin{array}{c}\text { A3 } \\
\text { A771726 }\end{array}$ & $\begin{array}{ll}- & \text { DHODH inhibitor } \\
\text { - } & \text { Inhibition of de novo pyrimidine biosynthesis }\end{array}$ \\
\hline & $\begin{array}{l}\text { acridone } \\
\text { bredinin }\end{array}$ & $\begin{array}{ll}- & \text { IMPDH inhibitor } \\
\text { - } & \text { Inhibition of de novo purine biosynthesis }\end{array}$ \\
\hline & 3-deazaneplanocin & $\begin{array}{l}\text { Inhibition of SAHH activity which is important in viral } \\
\text { mRNA capped structure }\end{array}$ \\
\hline & $\begin{array}{l}\text { ouabain } \\
\text { bufalin }\end{array}$ & $\begin{array}{ll}- & \text { ATP1A1 inhibitor } \\
\text { - } & \text { Preventing interaction with viral NP }\end{array}$ \\
\hline & rocaglamide & $\begin{array}{ll}\text { - } & \text { PHB inhibitor } \\
\text { - } & \text { Preventing interaction with viral NP }\end{array}$ \\
\hline \multirow{6}{*}{$\begin{array}{l}\text { Virion assembly } \\
\text { and budding }\end{array}$} & 2-hydroxymyristic acid & $\begin{array}{l}\text { - Inhibition of NMT which mediates myristoylation of } \\
\text { Z protein } \\
\text { - } \quad \text { Blocking Z-mediated budding }\end{array}$ \\
\hline & valproic acid & $\begin{array}{l}\text { Altering lipid composition of cellular membranes which is } \\
\text { critical in virus budding }\end{array}$ \\
\hline & compound 0013 & $\begin{array}{l}\text { - } \quad \text { Tsg101 inhibitor } \\
\text { - } \quad \text { Blocking interaction between Tsg101 and viral Z protein } \\
\text { that is required for virion egress }\end{array}$ \\
\hline & compound1 & $\begin{array}{l}\text { - Inhibiting the interaction between Nedd } 4 \text { and } \mathrm{Z} \text { protein, } \\
\text { blocking viral budding }\end{array}$ \\
\hline & BEZ-235 & $\begin{array}{ll}\text { - } & \text { PI3K inhibitor } \\
\text { - } & \text { Inhibition of Z-mediated budding via } \\
\text { unknown mechanism }\end{array}$ \\
\hline & KP-146 & Dual roles in viral genome replication and budding \\
\hline
\end{tabular}




\section{High-Throughput Screening for Discovery of Anti-Mammarenaviral Drugs}

The development of mammarenavirus reverse genetics (RG) systems has provided investigators with a novel and powerful approach for the investigation of the cis-acting sequences and trans-acting factors that control arenavirus replication, gene expression, and budding, as well as the rescue of infectious mammarenaviruses from cloned cDNAs. These advances in mammarenavirus molecular genetics have facilitated the generation of recombinant mammarenaviruses expressing reporter genes of interest that have enabled the development of cell-based assays and HTS strategies to identify novel anti-mammarenaviral drugs and assess how they target each of the different steps of the virus life cycle [36]. Different strategies, including the development of tri-segmented mammarenaviruses [36] and the use of the self-cleaving P2A linker to facilitate expression of a reporter gene and NP from the same bicistronic NP mRNA [73], have been used to generate these recombinant mammarenaviruses.

However, the use of recombinant infectious HF mammarenaviruses expressing reporter genes for antiviral drug screening campaigns or the investigation of drug mechanism of action would face the complications imposed by the requirement of BSL4 biocontainment. Hence, the advantage of the implementation of RG approaches to develop non-infectious cell-based assays recreating each of the key steps of the virus life cycle and that is amenable to HTS, which can be used without the need of a high-level biocontainment facility. Thus, a number of different platforms have been developed to screen for compounds capable of inhibiting cell entry mediated by GPs of different HF mammarenaviruses, using pseudotype viruses [124-126]. Likewise, the biosynthetic processes of replication and transcription of HF mammarenavirus genomes can be mimicked using cell-based minireplicon, or minigenome (MG) systems [127]. These cell-based MG systems are based on the intracellular reconstitution of a functional vRNP directing expression of a reporter gene whose expression level serves as a surrogate of the vRNP activity. For this, cells are transfected with plasmids expressing the viral trans-acting factors L and NP, together with a plasmid that allows for intracellular synthesis of an RNA containing the open reading frame of a reporter gene under the control of the cis-acting regulatory sequences of the $S$ or L genome RNA [54]. In addition to these transient transfection-based MG systems, cell lines have been generated to constitutively express a functional, non-infectious vRNP of LCMV or LASV [128]. This overcomes some technical complications related to transient transfection in the context of HTS. Thus, cell lines expressing LCMV and LASV functional vRNPs were successfully used to screen different compound libraries, resulting in the identification of a number of hits that were confirmed to exhibit antiviral activity against infectious LCMV and LASV [128].

Generation of infectious virus-like particle (iVLP) systems containing functional virus MGs allows for modeling of not only viral genome replication but also cell entry and budding [129]. A chimeric protein consisting of a secretion deficient form of Gaussia luciferase (GLuc) fused to the C-terminus of LASV Z protein was successfully used to develop a cell-based assay to quantify Z-mediated budding activity. This assay has features compatible with its use in HTS [130], as levels of GLuc in the tissue culture supernatant serve as an accurate surrogate of $Z$ budding activity.

\section{Drug Repurposing Strategy}

The Discovery and development of novel drugs require significant investments and resources and an average processing time for market authorization of 10 to 17 years [131]. The rapid development of antiviral therapeutics is important to combat emerging viruses. Finding novel applications of clinically approved drugs can accelerate the drug development process and significantly reduce risks during clinical trials assessing the new drug application. Accordingly, repurposing existing drugs is considered an attractive strategy to combat emerging viral infections [132]. This has been illustrated by efforts to combat the current COVID-19 pandemic, where screening of libraries of already approved drugs resulted in the rapid identification of anti-SARS-CoV-2 drug candidates that were very rapidly advanced to clinical trials [133]. Among the listed compounds in Table 1, ribavirin, arbidol and favipiravir are currently being tested in COVID-19 patients in clinical trials [133]. 
Screening of a library of FDA-approved drugs using VSV pseudotyped with LASV GP identified a number of inhibitors of LASV GP-mediated cell entry [125,134]. Likewise, screening of the Repurposing, Focused Rescue, and Accelerated Medchem (ReFRAME) library identified several potent anti-mammarenaviral compounds [135]. Importantly, selected hits initially identified based on their anti-LCMV activity, which were confirmed to show potent antiviral activity against the HF causing mammarenaviruses LASV and JUNV. These compounds exerted their antiviral activity via targeting host cellular factors, including enzymes required for pyrimidine and purine biosynthesis, regulators of apoptosis, and the mitochondrial electron transport complex III [135]. Recently, this ReFRAME library was used to screen for antiviral drugs against SARS-CoV-2, and the existing pharmacological and safety data on the identified hits will facilitate their rapid testing in the clinic [136]. In addition to HTS formats to rapidly identify novel targets and antiviral drug candidates, function-focus based assays have also been successfully used to identify compounds that could be repurposed as antiviral drugs. For example, screening of a collection of kinase inhibitors identified several cellular kinases that were involved in LASV GP-mediated viral entry, including protein kinase $C$, phosphoinositide 3-kinase, and human hepatocyte growth factor receptor (HGFR), which is a receptor tyrosine kinase [137].

\section{Conclusions and Future Perspectives}

As documented in this review, significant efforts have been dedicated to finding effective antiviral drugs against human pathogenic mammarenaviruses. Different screening platforms have identified a number of antiviral drug candidates with potent activity in cell-based infection assays. However, for the majority of the identified hits, there is only very limited information regarding their in vivo efficacy. To advance the development of novel effective antiviral drugs, further validation should be conducted using appropriate in vivo models of mammarenavirus disease, including non-human primates.

Drug repurposing approaches have identified a number of host cell factors as attractive antiviral targets for which drugs with a good safety profile have been already documented, which should facilitate the assessment of their efficacy in vivo using appropriate animal models of mammarenavirus induced disease. Since different viruses may share some key host cell functions to complete their life cycle, a host-targeting strategy would be an attractive approach for the development of broad-spectrum antiviral therapeutics. Synergistic antiviral effects have been documented in combination therapies of approved drugs, as illustrated by the results of combination therapy of ribavirin and favipiravir against LASV infection in pre-clinical [87] and clinical [138] studies. Likewise, combination therapy of arbidol with aripiprazole or sertraline resulted in synergistic inhibition of pseudotyped viruses with GPs from LASV and JUNV [139]. Synergistic effects are likely to be facilitated by combination therapy with drugs targeting different steps of the virus life cycle. To identify combinations for antiviral therapeutics, modern computational approaches, including available data libraries and analytical resources [140], would be promising tools by which data and text mining could identify potential drug combinations for further experimental validations.

Author Contributions: Conceptualization, Y.-J.K., V.V. and J.C.d.1.T.; writing-original draft preparation, Y.-J.K. and V.V.; writing-review and editing, Y.-J.K., V.V. and J.C.d.l.T.; visualization, Y.-J.K.; supervision, J.C.d.l.T.; project administration, J.C.d.l.T.; funding acquisition, J.C.d.1.T. All authors have read and agreed to the published version of the manuscript.

Funding: This work was supported by the NIH/NIAID grant RO1AI125626.

Institutional Review Board Statement: Not applicable.

Informed Consent Statement: Not applicable.

Acknowledgments: All figures were created with BioRender.com (accessed on 1 May 2021). This is the manuscript \#30091 from The Scripps Research Institute.

Conflicts of Interest: The authors declare no conflict of interest. 


\section{References}

1. Radoshitzky, S.R.; Buchmeier, M.J.; Charrel, R.N.; Clegg, J.C.S.; Gonzalez, J.J.; Gunther, S.; Hepojoki, J.; Kuhn, J.H.; Lukashevich, I.S.; Romanowski, V.; et al. ICTV Virus Taxonomy Profile: Arenaviridae. J. Gen. Virol. 2019, 100, 1200-1201. [CrossRef]

2. Buchmeier, M.J.; Peters, C.J.; de la Torre, J.C. Arenaviridae: The viruses and their replication. In Field's Virology, 5th ed.; Knipe, D.M., Holey, P.M., Eds.; Lippincott Williams \& Wilkins: Philadelphia, PA, USA, 2007; Volume 2, pp. 1791-1851.

3. Brisse, M.E.; Ly, H. Hemorrhagic Fever-Causing Arenaviruses: Lethal Pathogens and Potent Immune Suppressors. Front. Immunol. 2019, 10, 372. [CrossRef]

4. Shao, J.; Liang, Y.; Ly, H. Human hemorrhagic Fever causing arenaviruses: Molecular mechanisms contributing to virus virulence and disease pathogenesis. Pathogens 2015, 4, 283-306. [CrossRef]

5. Schieffelin, J. Treatment of Arenavirus Infections. Curr. Treat. Options Infect. Dis. 2015, 7, 261-270. [CrossRef]

6. McKee, K.T., Jr.; Oro, J.G.; Kuehne, A.I.; Spisso, J.A.; Mahlandt, B.G. Candid No. 1 Argentine hemorrhagic fever vaccine protects against lethal Junin virus challenge in rhesus macaques. Intervirology 1992, 34, 154-163. [CrossRef]

7. Maiztegui, J.I.; McKee, K.T., Jr.; Barrera Oro, J.G.; Harrison, L.H.; Gibbs, P.H.; Feuillade, M.R.; Enria, D.A.; Briggiler, A.M.; Levis, S.C.; Ambrosio, A.M.; et al. Protective efficacy of a live attenuated vaccine against Argentine hemorrhagic fever. AHF Study Group. J. Infect. Dis. 1998, 177, 277-283. [CrossRef] [PubMed]

8. Grant, A.; Seregin, A.; Huang, C.; Kolokoltsova, O.; Brasier, A.; Peters, C.; Paessler, S. Junin virus pathogenesis and virus replication. Viruses 2012, 4, 2317-2339. [CrossRef]

9. Neuman, B.W.; Adair, B.D.; Burns, J.W.; Milligan, R.A.; Buchmeier, M.J.; Yeager, M. Complementarity in the supramolecular design of arenaviruses and retroviruses revealed by electron cryomicroscopy and image analysis. J. Virol. 2005, 79, 3822-3830 [CrossRef] [PubMed]

10. Zhou, S.; Cerny, A.M.; Zacharia, A.; Fitzgerald, K.A.; Kurt-Jones, E.A.; Finberg, R.W. Induction and inhibition of type I interferon responses by distinct components of lymphocytic choriomeningitis virus. J. Virol. 2010, 84, 9452-9462. [CrossRef] [PubMed]

11. Ferron, F.; Weber, F.; de la Torre, J.C.; Reguera, J. Transcription and replication mechanisms of Bunyaviridae and Arenaviridae L proteins. Virus Res. 2017, 234, 118-134. [CrossRef] [PubMed]

12. Shao, J.; Liang, Y.; Ly, H. Roles of Arenavirus Z Protein in Mediating Virion Budding, Viral Transcription-Inhibition and Interferon-Beta Suppression. Methods Mol. Biol. 2018, 1604, 217-227. [CrossRef] [PubMed]

13. Li, S.; Sun, Z.; Pryce, R.; Parsy, M.L.; Fehling, S.K.; Schlie, K.; Siebert, C.A.; Garten, W.; Bowden, T.A.; Strecker, T.; et al. Acidic pH-Induced Conformations and LAMP1 Binding of the Lassa Virus Glycoprotein Spike. PLoS Pathog. 2016, 12, e1005418. [CrossRef]

14. Fehling, S.K.; Lennartz, F.; Strecker, T. Multifunctional nature of the arenavirus RING finger protein Z. Viruses 2012, 4, $2973-3011$. [CrossRef] [PubMed]

15. Hastie, K.M.; Kimberlin, C.R.; Zandonatti, M.A.; MacRae, I.J.; Saphire, E.O. Structure of the Lassa virus nucleoprotein reveals a dsRNA-specific 3' to 5' exonuclease activity essential for immune suppression. Proc. Natl. Acad. Sci. USA 2011, 108, 2396-2401. [CrossRef]

16. Martinez-Sobrido, L.; Zuniga, E.I.; Rosario, D.; Garcia-Sastre, A.; de la Torre, J.C. Inhibition of the type I interferon response by the nucleoprotein of the prototypic arenavirus lymphocytic choriomeningitis virus. J. Virol. 2006, 80, 9192-9199. [CrossRef]

17. Lenz, O.; ter Meulen, J.; Klenk, H.D.; Seidah, N.G.; Garten, W. The Lassa virus glycoprotein precursor GP-C is proteolytically processed by subtilase SKI-1/S1P. Proc. Natl. Acad. Sci. USA 2001, 98, 12701-12705. [CrossRef] [PubMed]

18. Eschli, B.; Quirin, K.; Wepf, A.; Weber, J.; Zinkernagel, R.; Hengartner, H. Identification of an N-terminal trimeric coiled-coil core within arenavirus glycoprotein 2 permits assignment to class I viral fusion proteins. J. Virol. 2006, 80, 5897-5907. [CrossRef] [PubMed]

19. Kunz, S.; Edelmann, K.H.; de la Torre, J.C.; Gorney, R.; Oldstone, M.B. Mechanisms for lymphocytic choriomeningitis virus glycoprotein cleavage, transport, and incorporation into virions. Virology 2003, 314, 168-178. [CrossRef]

20. Di Simone, C.; Zandonatti, M.A.; Buchmeier, M.J. Acidic pH triggers LCMV membrane fusion activity and conformational change in the glycoprotein spike. Virology 1994, 198, 455-465. [CrossRef]

21. Igonet, S.; Vaney, M.C.; Vonrhein, C.; Bricogne, G.; Stura, E.A.; Hengartner, H.; Eschli, B.; Rey, F.A. X-ray structure of the arenavirus glycoprotein GP2 in its postfusion hairpin conformation. Proc. Natl. Acad. Sci. USA 2011, 108, 19967-19972. [CrossRef]

22. Eichler, R.; Lenz, O.; Garten, W.; Strecker, T. The role of single N-glycans in proteolytic processing and cell surface transport of the Lassa virus glycoprotein GP-C. Virol. J. 2006, 3, 41. [CrossRef] [PubMed]

23. York, J.; Romanowski, V.; Lu, M.; Nunberg, J.H. The signal peptide of the Junin arenavirus envelope glycoprotein is myristoylated and forms an essential subunit of the mature G1-G2 complex. J. Virol. 2004, 78, 10783-10792. [CrossRef] [PubMed]

24. Ortin, J.; Martin-Benito, J. The RNA synthesis machinery of negative-stranded RNA viruses. Virology 2015, 479-480, 532-544. [CrossRef] [PubMed]

25. Perez, M.; Craven, R.C.; de la Torre, J.C. The small RING finger protein Z drives arenavirus budding: Implications for antiviral strategies. Proc. Natl. Acad. Sci. USA 2003, 100, 12978-12983. [CrossRef]

26. Campbell Dwyer, E.J.; Lai, H.; MacDonald, R.C.; Salvato, M.S.; Borden, K.L. The lymphocytic choriomeningitis virus RING protein $\mathrm{Z}$ associates with eukaryotic initiation factor $4 \mathrm{E}$ and selectively represses translation in a RING-dependent manner. J. Virol. 2000, 74, 3293-3300. [CrossRef]

27. Volpon, L.; Osborne, M.J.; Capul, A.A.; de la Torre, J.C.; Borden, K.L. Structural characterization of the Z RING-eIF4E complex reveals a distinct mode of control for eIF4E. Proc. Natl. Acad. Sci. USA 2010, 107, 5441-5446. [CrossRef] 
28. Borden, K.L.; Campbell Dwyer, E.J.; Salvato, M.S. An arenavirus RING (zinc-binding) protein binds the oncoprotein promyelocyte leukemia protein (PML) and relocates PML nuclear bodies to the cytoplasm. J. Virol. 1998, 72, 758-766. [CrossRef]

29. Djavani, M.; Rodas, J.; Lukashevich, I.S.; Horejsh, D.; Pandolfi, P.P.; Borden, K.L.; Salvato, M.S. Role of the promyelocytic leukemia protein PML in the interferon sensitivity of lymphocytic choriomeningitis virus. J. Virol. 2001, 75, 6204-6208. [CrossRef]

30. Urata, S.; Yasuda, J. Molecular mechanism of arenavirus assembly and budding. Viruses 2012, 4, 2049-2079. [CrossRef] [PubMed]

31. Kranzusch, P.J.; Whelan, S.P. Arenavirus Z protein controls viral RNA synthesis by locking a polymerase-promoter complex. Proc. Natl. Acad. Sci. USA 2011, 108, 19743-19748. [CrossRef]

32. Cornu, T.I.; de la Torre, J.C. RING finger Z protein of lymphocytic choriomeningitis virus (LCMV) inhibits transcription and RNA replication of an LCMV S-segment minigenome. J. Virol. 2001, 75, 9415-9426. [CrossRef] [PubMed]

33. Capul, A.A.; Perez, M.; Burke, E.; Kunz, S.; Buchmeier, M.J.; de la Torre, J.C. Arenavirus Z-glycoprotein association requires Z myristoylation but not functional RING or late domains. J. Virol. 2007, 81, 9451-9460. [CrossRef] [PubMed]

34. Ortiz-Riano, E.; Cheng, B.Y.; de la Torre, J.C.; Martinez-Sobrido, L. The C-terminal region of lymphocytic choriomeningitis virus nucleoprotein contains distinct and segregable functional domains involved in NP-Z interaction and counteraction of the type I interferon response. J. Virol. 2011, 85, 13038-13048. [CrossRef]

35. Strecker, T.; Eichler, R.; Meulen, J.; Weissenhorn, W.; Dieter Klenk, H.; Garten, W.; Lenz, O. Lassa virus Z protein is a matrix protein and sufficient for the release of virus-like particles [corrected]. J. Virol. 2003, 77, 10700-10705. [CrossRef]

36. Martinez-Sobrido, L.; de la Torre, J.C. Reporter-Expressing, Replicating-Competent Recombinant Arenaviruses. Viruses 2016, 8. [CrossRef]

37. Perez, M.; de la Torre, J.C. Characterization of the genomic promoter of the prototypic arenavirus lymphocytic choriomeningitis virus. J. Virol. 2003, 77, 1184-1194. [CrossRef]

38. Pinschewer, D.D.; Perez, M.; de la Torre, J.C. Dual role of the lymphocytic choriomeningitis virus intergenic region in transcription termination and virus propagation. J. Virol. 2005, 79, 4519-4526. [CrossRef]

39. Iwasaki, M.; Cubitt, B.; Sullivan, B.M.; de la Torre, J.C. The High Degree of Sequence Plasticity of the Arenavirus Noncoding Intergenic Region (IGR) Enables the Use of a Nonviral Universal Synthetic IGR To Attenuate Arenaviruses. J. Virol. 2016, 90, 3187-3197. [CrossRef] [PubMed]

40. Spiropoulou, C.F.; Kunz, S.; Rollin, P.E.; Campbell, K.P.; Oldstone, M.B. New World arenavirus clade C, but not clade A and B viruses, utilizes alpha-dystroglycan as its major receptor. J. Virol. 2002, 76, 5140-5146. [CrossRef]

41. Cao, W.; Henry, M.D.; Borrow, P.; Yamada, H.; Elder, J.H.; Ravkov, E.V.; Nichol, S.T.; Compans, R.W.; Campbell, K.P.; Oldstone, M.B. Identification of alpha-dystroglycan as a receptor for lymphocytic choriomeningitis virus and Lassa fever virus. Science 1998, 282, 2079-2081. [CrossRef]

42. Radoshitzky, S.R.; Abraham, J.; Spiropoulou, C.F.; Kuhn, J.H.; Nguyen, D.; Li, W.; Nagel, J.; Schmidt, P.J.; Nunberg, J.H.; Andrews, N.C.; et al. Transferrin receptor 1 is a cellular receptor for New World haemorrhagic fever arenaviruses. Nature 2007, 446, 92-96. [CrossRef]

43. Hallam, S.J.; Koma, T.; Maruyama, J.; Paessler, S. Review of Mammarenavirus Biology and Replication. Front. Microbiol. 2018, 9, 1751. [CrossRef]

44. Raaben, M.; Jae, L.T.; Herbert, A.S.; Kuehne, A.I.; Stubbs, S.H.; Chou, Y.Y.; Blomen, V.A.; Kirchhausen, T.; Dye, J.M.; Brummelkamp, T.R.; et al. NRP2 and CD63 Are Host Factors for Lujo Virus Cell Entry. Cell Host Microbe 2017, 22, 688-696 e685. [CrossRef]

45. Bielenberg, D.R.; Pettaway, C.A.; Takashima, S.; Klagsbrun, M. Neuropilins in neoplasms: Expression, regulation, and function. Exp. Cell Res. 2006, 312, 584-593. [CrossRef] [PubMed]

46. Aung, N.Y.; Ohe, R.; Meng, H.; Kabasawa, T.; Yang, S.; Kato, T.; Yamakawa, M. Specific Neuropilins Expression in Alveolar Macrophages among Tissue-Specific Macrophages. PLoS ONE 2016, 11, e0147358. [CrossRef] [PubMed]

47. Immormino, R.M.; Lauzier, D.C.; Nakano, H.; Hernandez, M.L.; Alexis, N.E.; Ghio, A.J.; Tilley, S.L.; Doerschuk, C.M.; Peden, D.B.; Cook, D.N.; et al. Neuropilin-2 regulates airway inflammatory responses to inhaled lipopolysaccharide. Am. J. Physiol. Lung Cell Mol. Physiol. 2018, 315, L202-L211. [CrossRef]

48. Rojek, J.M.; Sanchez, A.B.; Nguyen, N.T.; de la Torre, J.C.; Kunz, S. Different mechanisms of cell entry by human-pathogenic Old World and New World arenaviruses. J. Virol. 2008, 82, 7677-7687. [CrossRef] [PubMed]

49. Rojek, J.M.; Perez, M.; Kunz, S. Cellular entry of lymphocytic choriomeningitis virus. J. Virol. 2008, 82, 1505-1517. [CrossRef]

50. Pasqual, G.; Rojek, J.M.; Masin, M.; Chatton, J.Y.; Kunz, S. Old world arenaviruses enter the host cell via the multivesicular body and depend on the endosomal sorting complex required for transport. PLoS Pathog. 2011, 7, e1002232. [CrossRef]

51. Jae, L.T.; Raaben, M.; Herbert, A.S.; Kuehne, A.I.; Wirchnianski, A.S.; Soh, T.K.; Stubbs, S.H.; Janssen, H.; Damme, M.; Saftig, P.; et al. Virus entry. Lassa virus entry requires a trigger-induced receptor switch. Science 2014, 344, 1506-1510. [CrossRef]

52. Di Simone, C.; Buchmeier, M.J. Kinetics and $\mathrm{pH}$ dependence of acid-induced structural changes in the lymphocytic choriomeningitis virus glycoprotein complex. Virology 1995, 209, 3-9. [CrossRef]

53. Lopez, N.; Jacamo, R.; Franze-Fernandez, M.T. Transcription and RNA replication of tacaribe virus genome and antigenome analogs require $\mathrm{N}$ and L proteins: Z protein is an inhibitor of these processes. J. Virol. 2001, 75, 12241-12251. [CrossRef] [PubMed]

54. Lee, K.J.; Novella, I.S.; Teng, M.N.; Oldstone, M.B.; de La Torre, J.C. NP and L proteins of lymphocytic choriomeningitis virus (LCMV) are sufficient for efficient transcription and replication of LCMV genomic RNA analogs. J. Virol. 2000, 74, 3470-3477. [CrossRef] 
55. King, B.R.; Samacoits, A.; Eisenhauer, P.L.; Ziegler, C.M.; Bruce, E.A.; Zenklusen, D.; Zimmer, C.; Mueller, F.; Botten, J. Visualization of Arenavirus RNA Species in Individual Cells by Single-Molecule Fluorescence In Situ Hybridization Suggests a Model of Cyclical Infection and Clearance during Persistence. J. Virol. 2018, 92. [CrossRef] [PubMed]

56. Hass, M.; Golnitz, U.; Muller, S.; Becker-Ziaja, B.; Gunther, S. Replicon system for Lassa virus. J. Virol. 2004, 78, 13793-13803. [CrossRef]

57. Lopez, N.; Franze-Fernandez, M.T. A single stem-loop structure in Tacaribe arenavirus intergenic region is essential for transcription termination but is not required for a correct initiation of transcription and replication. Virus Res. 2007, 124, 237-244. [CrossRef]

58. Raju, R.; Raju, L.; Hacker, D.; Garcin, D.; Compans, R.; Kolakofsky, D. Nontemplated bases at the 5' ends of Tacaribe virus mRNAs. Virology 1990, 174, 53-59. [CrossRef]

59. Lelke, M.; Brunotte, L.; Busch, C.; Gunther, S. An N-terminal region of Lassa virus L protein plays a critical role in transcription but not replication of the virus genome. J. Virol. 2010, 84, 1934-1944. [CrossRef] [PubMed]

60. Vogel, D.; Rosenthal, M.; Gogrefe, N.; Reindl, S.; Gunther, S. Biochemical characterization of the Lassa virus L protein. J. Biol. Chem. 2019, 294, 8088-8100. [CrossRef]

61. Emonet, S.E.; Urata, S.; de la Torre, J.C. Arenavirus reverse genetics: New approaches for the investigation of arenavirus biology and development of antiviral strategies. Virology 2011, 411, 416-425. [CrossRef] [PubMed]

62. Marq, J.B.; Hausmann, S.; Veillard, N.; Kolakofsky, D.; Garcin, D. Short double-stranded RNAs with an overhanging 5' pppnucleotide, as found in arenavirus genomes, act as RIG-I decoys. J. Biol. Chem. 2011, 286, 6108-6116. [CrossRef]

63. Linero, F.; Welnowska, E.; Carrasco, L.; Scolaro, L. Participation of eIF4F complex in Junin virus infection: Blockage of eIF4E does not impair virus replication. Cell Microbiol. 2013, 15, 1766-1782. [CrossRef]

64. Bieniasz, P.D. Late budding domains and host proteins in enveloped virus release. Virology 2006, 344, 55-63. [CrossRef] [PubMed]

65. Shtanko, O.; Imai, M.; Goto, H.; Lukashevich, I.S.; Neumann, G.; Watanabe, T.; Kawaoka, Y. A role for the C terminus of Mopeia virus nucleoprotein in its incorporation into Z protein-induced virus-like particles. J. Virol. 2010, 84, 5415-5422. [CrossRef] [PubMed]

66. Urata, S.; Noda, T.; Kawaoka, Y.; Yokosawa, H.; Yasuda, J. Cellular factors required for Lassa virus budding. J. Virol. 2006, 80, 4191-4195. [CrossRef] [PubMed]

67. Votteler, J.; Sundquist, W.I. Virus budding and the ESCRT pathway. Cell Host Microbe. 2013, 14, 232-241. [CrossRef]

68. Meng, B.; Lever, A.M.L. The Interplay between ESCRT and Viral Factors in the Enveloped Virus Life Cycle. Viruses 2021, 13, 324 [CrossRef] [PubMed]

69. Bolken, T.C.; Laquerre, S.; Zhang, Y.; Bailey, T.R.; Pevear, D.C.; Kickner, S.S.; Sperzel, L.E.; Jones, K.F.; Warren, T.K.; Amanda Lund, S.; et al. Identification and characterization of potent small molecule inhibitor of hemorrhagic fever New World arenaviruses. Antivir. Res. 2006, 69, 86-97. [CrossRef]

70. Larson, R.A.; Dai, D.; Hosack, V.T.; Tan, Y.; Bolken, T.C.; Hruby, D.E.; Amberg, S.M. Identification of a broad-spectrum arenavirus entry inhibitor. J. Virol. 2008, 82, 10768-10775. [CrossRef]

71. Cashman, K.A.; Smith, M.A.; Twenhafel, N.A.; Larson, R.A.; Jones, K.F.; Allen, R.D., III; Dai, D.; Chinsangaram, J.; Bolken, T.C.; Hruby, D.E.; et al. Evaluation of Lassa antiviral compound ST-193 in a guinea pig model. Antivir. Res. 2011, 90, 70-79. [CrossRef]

72. Madu, I.G.; Files, M.; Gharaibeh, D.N.; Moore, A.L.; Jung, K.H.; Gowen, B.B.; Dai, D.; Jones, K.F.; Tyavanagimatt, S.R.; Burgeson, J.R.; et al. A potent Lassa virus antiviral targets an arenavirus virulence determinant. PLoS Pathog. 2018, 14, e1007439. [CrossRef]

73. Ngo, N.; Henthorn, K.S.; Cisneros, M.I.; Cubitt, B.; Iwasaki, M.; de la Torre, J.C.; Lama, J. Identification and Mechanism of Action of a Novel Small-Molecule Inhibitor of Arenavirus Multiplication. J. Virol. 2015, 89, 10924-10933. [CrossRef]

74. Spence, J.S.; Melnik, L.I.; Badani, H.; Wimley, W.C.; Garry, R.F. Inhibition of arenavirus infection by a glycoprotein-derived peptide with a novel mechanism. J. Virol. 2014, 88, 8556-8564. [CrossRef] [PubMed]

75. Blaising, J.; Polyak, S.J.; Pecheur, E.I. Arbidol as a broad-spectrum antiviral: An update. Antivir. Res. 2014, 107, 84-94. [CrossRef] [PubMed]

76. Pecheur, E.I.; Borisevich, V.; Halfmann, P.; Morrey, J.D.; Smee, D.F.; Prichard, M.; Mire, C.E.; Kawaoka, Y.; Geisbert, T.W.; Polyak, S.J. The Synthetic Antiviral Drug Arbidol Inhibits Globally Prevalent Pathogenic Viruses. J. Virol. 2016, 90, 3086-3092. [CrossRef] [PubMed]

77. Hulseberg, C.E.; Feneant, L.; Szymanska-de Wijs, K.M.; Kessler, N.P.; Nelson, E.A.; Shoemaker, C.J.; Schmaljohn, C.S.; Polyak, S.J.; White, J.M. Arbidol and Other Low-Molecular-Weight Drugs That Inhibit Lassa and Ebola Viruses. J. Virol. 2019, 93. [CrossRef]

78. Tang, K.; He, S.; Zhang, X.; Guo, J.; Chen, Q.; Yan, F.; Banadyga, L.; Zhu, W.; Qiu, X.; Guo, Y. Tangeretin, an extract from Citrus peels, blocks cellular entry of arenaviruses that cause viral hemorrhagic fever. Antivir. Res. 2018, 160, 87-93. [CrossRef] [PubMed]

79. Torriani, G.; Trofimenko, E.; Mayor, J.; Fedeli, C.; Moreno, H.; Michel, S.; Heulot, M.; Chevalier, N.; Zimmer, G.; Shrestha, N.; et al. Identification of Clotrimazole Derivatives as Specific Inhibitors of Arenavirus Fusion. J. Virol. 2019, 93. [CrossRef]

80. Zhang, X.; Yan, F.; Tang, K.; Chen, Q.; Guo, J.; Zhu, W.; He, S.; Banadyga, L.; Qiu, X.; Guo, Y. Identification of a clinical compound losmapimod that blocks Lassa virus entry. Antivir. Res. 2019, 167, 68-77. [CrossRef] [PubMed]

81. Moeschler, S.; Locher, S.; Zimmer, G. 1-Benzyl-3-cetyl-2-methylimidazolium Iodide (NH125) Is a Broad-Spectrum Inhibitor of Virus Entry with Lysosomotropic Features. Viruses 2018, 10. [CrossRef]

82. Friesland, A.; Zhao, Y.; Chen, Y.H.; Wang, L.; Zhou, H.; Lu, Q. Small molecule targeting Cdc42-intersectin interaction disrupts Golgi organization and suppresses cell motility. Proc. Natl. Acad. Sci. USA 2013, 110, 1261-1266. [CrossRef]

83. Chou, Y.Y.; Cuevas, C.; Carocci, M.; Stubbs, S.H.; Ma, M.; Cureton, D.K.; Chao, L.; Evesson, F.; He, K.; Yang, P.L.; et al. Identification and Characterization of a Novel Broad-Spectrum Virus Entry Inhibitor. J. Virol. 2016, 90, 4494-4510. [CrossRef] 
84. Zhang, X.; Tang, K.; Guo, Y. The antifungal isavuconazole inhibits the entry of lassa virus by targeting the stable signal peptide-GP2 subunit interface of lassa virus glycoprotein. Antivir. Res. 2020, 174, 104701. [CrossRef]

85. Wang, M.K.; Ren, T.; Liu, H.; Lim, S.Y.; Lee, K.; Honko, A.; Zhou, H.; Dyall, J.; Hensley, L.; Gartin, A.K.; et al. Critical role for cholesterol in Lassa fever virus entry identified by a novel small molecule inhibitor targeting the viral receptor LAMP1. PLoS Pathog. 2018, 14, e1007322. [CrossRef] [PubMed]

86. McCormick, J.B.; King, I.J.; Webb, P.A.; Scribner, C.L.; Craven, R.B.; Johnson, K.M.; Elliott, L.H.; Belmont-Williams, R. Lassa fever. Effective therapy with ribavirin. N. Engl. J. Med. 1986, 314, 20-26. [CrossRef] [PubMed]

87. Oestereich, L.; Rieger, T.; Ludtke, A.; Ruibal, P.; Wurr, S.; Pallasch, E.; Bockholt, S.; Krasemann, S.; Munoz-Fontela, C.; Gunther, S. Efficacy of Favipiravir Alone and in Combination With Ribavirin in a Lethal, Immunocompetent Mouse Model of Lassa Fever. J. Infect. Dis. 2016, 213, 934-938. [CrossRef] [PubMed]

88. Feld, J.J.; Hoofnagle, J.H. Mechanism of action of interferon and ribavirin in treatment of hepatitis C. Nature 2005, 436, 967-972. [CrossRef]

89. Lau, J.Y.; Tam, R.C.; Liang, T.J.; Hong, Z. Mechanism of action of ribavirin in the combination treatment of chronic HCV infection. Hepatology 2002, 35, 1002-1009. [CrossRef]

90. Carrillo-Bustamante, P.; Nguyen, T.H.T.; Oestereich, L.; Gunther, S.; Guedj, J.; Graw, F. Determining Ribavirin's mechanism of action against Lassa virus infection. Sci. Rep. 2017, 7, 1-12. [CrossRef] [PubMed]

91. Furuta, Y.; Komeno, T.; Nakamura, T. Favipiravir (T-705), a broad spectrum inhibitor of viral RNA polymerase. Proc. Jpn. Acad. Ser. B Phys. Biol. Sci. 2017, 93, 449-463. [CrossRef]

92. Furuta, Y.; Gowen, B.B.; Takahashi, K.; Shiraki, K.; Smee, D.F.; Barnard, D.L. Favipiravir (T-705), a novel viral RNA polymerase inhibitor. Antivir. Res. 2013, 100, 446-454. [CrossRef] [PubMed]

93. Warren, T.K.; Wells, J.; Panchal, R.G.; Stuthman, K.S.; Garza, N.L.; Van Tongeren, S.A.; Dong, L.; Retterer, C.J.; Eaton, B.P.; Pegoraro, G.; et al. Protection against filovirus diseases by a novel broad-spectrum nucleoside analogue BCX4430. Nature 2014, 508, 402-405. [CrossRef] [PubMed]

94. Neuman, B.W.; Bederka, L.H.; Stein, D.A.; Ting, J.P.; Moulton, H.M.; Buchmeier, M.J. Development of peptide-conjugated morpholino oligomers as pan-arenavirus inhibitors. Antimicrob. Agents Chemother. 2011, 55, 4631-4638. [CrossRef] [PubMed]

95. Huang, K.W.; Hsu, K.C.; Chu, L.Y.; Yang, J.M.; Yuan, H.S.; Hsiao, Y.Y. Identification of Inhibitors for the DEDDh Family of Exonucleases and a Unique Inhibition Mechanism by Crystal Structure Analysis of CRN-4 Bound with 2-Morpholin-4ylethanesulfonate (MES). J. Med. Chem. 2016, 59, 8019-8029. [CrossRef]

96. Saez-Ayala, M.; Laban Yekwa, E.; Mondielli, C.; Roux, L.; Hernandez, S.; Bailly, F.; Cotelle, P.; Rogolino, D.; Canard, B.; Ferron, F.; et al. Metal chelators for the inhibition of the lymphocytic choriomeningitis virus endonuclease domain. Antivir. Res. 2019, 162, 79-89. [CrossRef] [PubMed]

97. Sepulveda, C.S.; Garcia, C.C.; Damonte, E.B. Inhibition of arenavirus infection by thiuram and aromatic disulfides. Antivir. Res. 2010, 87, 329-337. [CrossRef]

98. Sepulveda, C.S.; Garcia, C.C.; Levingston Macleod, J.M.; Lopez, N.; Damonte, E.B. Targeting of arenavirus RNA synthesis by a carboxamide-derivatized aromatic disulfide with virucidal activity. PLoS ONE 2013, 8, e81251. [CrossRef] [PubMed]

99. Pasquato, A.; Cendron, L.; Kunz, S. Cleavage of the Glycoprotein of Arenaviruses. In Activation of Viruses by Host Proteases; Böttcher-Friebertshäuser, E., Garten, W., Klenk, H.D., Eds.; Springer International Publishing: Cham, Germany, 2018; pp. 47-70.

100. Pasquato, A.; Pullikotil, P.; Asselin, M.C.; Vacatello, M.; Paolillo, L.; Ghezzo, F.; Basso, F.; Di Bello, C.; Dettin, M.; Seidah, N.G. The proprotein convertase SKI-1/S1P. In vitro analysis of Lassa virus glycoprotein-derived substrates and ex vivo validation of irreversible peptide inhibitors. J. Biol. Chem. 2006, 281, 23471-23481. [CrossRef]

101. Rojek, J.M.; Pasqual, G.; Sanchez, A.B.; Nguyen, N.T.; de la Torre, J.C.; Kunz, S. Targeting the proteolytic processing of the viral glycoprotein precursor is a promising novel antiviral strategy against arenaviruses. J. Virol. 2010, 84, 573-584. [CrossRef]

102. Urata, S.; Yun, N.; Pasquato, A.; Paessler, S.; Kunz, S.; de la Torre, J.C. Antiviral activity of a small-molecule inhibitor of arenavirus glycoprotein processing by the cellular site 1 protease. J. Virol. 2011, 85, 795-803. [CrossRef]

103. Pasquato, A.; Rochat, C.; Burri, D.J.; Pasqual, G.; de la Torre, J.C.; Kunz, S. Evaluation of the anti-arenaviral activity of the subtilisin kexin isozyme-1/site-1 protease inhibitor PF-429242. Virology 2012, 423, 14-22. [CrossRef] [PubMed]

104. Urata, S.; de la Torre, J.C. Arenavirus budding. Adv. Virol. 2011, 2011, 180326. [CrossRef]

105. Perez, M.; Greenwald, D.L.; de la Torre, J.C. Myristoylation of the RING finger Z protein is essential for arenavirus budding. J. Virol. 2004, 78, 11443-11448. [CrossRef]

106. Russo, R.; Kemp, M.; Bhatti, U.F.; Pai, M.; Wakam, G.; Biesterveld, B.; Alam, H.B. Life on the battlefield: Valproic acid for combat applications. J. Trauma Acute Care Surg. 2020, 89, S69-S76. [CrossRef]

107. Vazquez-Calvo, A.; Martin-Acebes, M.A.; Saiz, J.C.; Ngo, N.; Sobrino, F.; de la Torre, J.C. Inhibition of multiplication of the prototypic arenavirus LCMV by valproic acid. Antivir. Res. 2013, 99, 172-179. [CrossRef] [PubMed]

108. Lu, J.; Han, Z.; Liu, Y.; Liu, W.; Lee, M.S.; Olson, M.A.; Ruthel, G.; Freedman, B.D.; Harty, R.N. A host-oriented inhibitor of Junin Argentine hemorrhagic fever virus egress. J. Virol. 2014, 88, 4736-4743. [CrossRef] [PubMed]

109. Yasuda, J.; Hunter, E.; Nakao, M.; Shida, H. Functional involvement of a novel Nedd4-like ubiquitin ligase on retrovirus budding. EMBO Rep. 2002, 3, 636-640. [CrossRef] 
110. Han, Z.; Lu, J.; Liu, Y.; Davis, B.; Lee, M.S.; Olson, M.A.; Ruthel, G.; Freedman, B.D.; Schnell, M.J.; Wrobel, J.E.; et al. Smallmolecule probes targeting the viral PPxY-host Nedd4 interface block egress of a broad range of RNA viruses. J. Virol. 2014, 88, 7294-7306. [CrossRef]

111. Urata, S.; Ngo, N.; de la Torre, J.C. The PI3K/Akt pathway contributes to arenavirus budding. J. Virol. 2012, 86, 4578-4585. [CrossRef] [PubMed]

112. Xing, J.; Ly, H.; Liang, Y. The Z proteins of pathogenic but not nonpathogenic arenaviruses inhibit RIG-I-like receptor-dependent interferon production. J. Virol. 2015, 89, 2944-2955. [CrossRef]

113. Ziegler, C.M.; Eisenhauer, P.; Kelly, J.A.; Dang, L.N.; Beganovic, V.; Bruce, E.A.; King, B.R.; Shirley, D.J.; Weir, M.E.; Ballif, B.A.; et al. A Proteomics Survey of Junin Virus Interactions with Human Proteins Reveals Host Factors Required for Arenavirus Replication. J. Virol. 2018, 92. [CrossRef]

114. Helguera, G.; Jemielity, S.; Abraham, J.; Cordo, S.M.; Martinez, M.G.; Rodriguez, J.A.; Bregni, C.; Wang, J.J.; Farzan, M.; Penichet, M.L.; et al. An antibody recognizing the apical domain of human transferrin receptor 1 efficiently inhibits the entry of all new world hemorrhagic Fever arenaviruses. J. Virol. 2012, 86, 4024-4028. [CrossRef]

115. Cross, R.W.; Mire, C.E.; Branco, L.M.; Geisbert, J.B.; Rowland, M.M.; Heinrich, M.L.; Goba, A.; Momoh, M.; Grant, D.S.; Fullah, M.; et al. Treatment of Lassa virus infection in outbred guinea pigs with first-in-class human monoclonal antibodies. Antivir. Res. 2016, 133, 218-222. [CrossRef] [PubMed]

116. Amanat, F.; Duehr, J.; Huang, C.; Paessler, S.; Tan, G.S.; Krammer, F. Monoclonal Antibodies with Neutralizing Activity and Fc-Effector Functions against the Machupo Virus Glycoprotein. J. Virol. 2020, 94. [CrossRef] [PubMed]

117. Robinson, J.E.; Hastie, K.M.; Cross, R.W.; Yenni, R.E.; Elliott, D.H.; Rouelle, J.A.; Kannadka, C.B.; Smira, A.A.; Garry, C.E.; Bradley, B.T.; et al. Most neutralizing human monoclonal antibodies target novel epitopes requiring both Lassa virus glycoprotein subunits. Nat. Commun. 2016, 7, 1-14. [CrossRef]

118. Ortiz-Riano, E.; Ngo, N.; Devito, S.; Eggink, D.; Munger, J.; Shaw, M.L.; de la Torre, J.C.; Martinez-Sobrido, L. Inhibition of arenavirus by A3, a pyrimidine biosynthesis inhibitor. J. Virol. 2014, 88, 878-889. [CrossRef] [PubMed]

119. Sepulveda, C.S.; Garcia, C.C.; Damonte, E.B. Antiviral activity of A771726, the active metabolite of leflunomide, against Junin virus. J. Med. Virol. 2018, 90, 819-827. [CrossRef] [PubMed]

120. Sepulveda, C.S.; Garcia, C.C.; Fascio, M.L.; D'Accorso, N.B.; Docampo Palacios, M.L.; Pellon, R.F.; Damonte, E.B. Inhibition of Junin virus RNA synthesis by an antiviral acridone derivative. Antivir. Res. 2012, 93, 16-22. [CrossRef] [PubMed]

121. Nair, V.; Chi, G.; Shu, Q.; Julander, J.; Smee, D.F. A heterocyclic molecule with significant activity against dengue virus. Bioorg. Med. Chem. Lett. 2009, 19, 1425-1427. [CrossRef] [PubMed]

122. Chen, Q.; Smith, A. l-like 3-deazaneplanocin analogues: Synthesis and antiviral properties. Bioorg. Med. Chem. Lett. 2019, 29, 126613. [CrossRef]

123. Iwasaki, M.; Minder, P.; Cai, Y.; Kuhn, J.H.; Yates, J.R., III; Torbett, B.E.; de la Torre, J.C. Interactome analysis of the lymphocytic choriomeningitis virus nucleoprotein in infected cells reveals ATPase $\mathrm{Na}^{+} / \mathrm{K}^{+}$transporting subunit Alpha 1 and prohibitin as host-cell factors involved in the life cycle of mammarenaviruses. PLoS Pathog. 2018, 14, e1006892. [CrossRef] [PubMed]

124. Lee, A.M.; Rojek, J.M.; Spiropoulou, C.F.; Gundersen, A.T.; Jin, W.; Shaginian, A.; York, J.; Nunberg, J.H.; Boger, D.L.; Oldstone, M.B.; et al. Unique small molecule entry inhibitors of hemorrhagic fever arenaviruses. J. Biol. Chem. 2008, 283, 18734-18742. [CrossRef]

125. Wang, P.; Liu, Y.; Zhang, G.; Wang, S.; Guo, J.; Cao, J.; Jia, X.; Zhang, L.; Xiao, G.; Wang, W. Screening and Identification of Lassa Virus Entry Inhibitors from an FDA-Approved Drug Library. J. Virol. 2018, 92. [CrossRef] [PubMed]

126. Lay Mendoza, M.F.; Acciani, M.D.; Levit, C.N.; Santa Maria, C.; Brindley, M.A. Monitoring Viral Entry in Real-Time Using a Luciferase Recombinant Vesicular Stomatitis Virus Producing SARS-CoV-2, EBOV, LASV, CHIKV, and VSV Glycoproteins. Viruses 2020, 12. [CrossRef] [PubMed]

127. Martinez-Sobrido, L.; Cheng, B.Y.; de la Torre, J.C. Reverse Genetics Approaches to Control Arenavirus. Methods Mol. Biol. 2016, 1403, 313-351. [CrossRef] [PubMed]

128. Cubitt, B.; Ortiz-Riano, E.; Cheng, B.Y.; Kim, Y.J.; Yeh, C.D.; Chen, C.Z.; Southall, N.O.E.; Zheng, W.; Martinez-Sobrido, L.; de la Torre, J.C. A cell-based, infectious-free, platform to identify inhibitors of lassa virus ribonucleoprotein (vRNP) activity. Antivir. Res. 2020, 173, 104667. [CrossRef] [PubMed]

129. Wendt, L.; Bostedt, L.; Hoenen, T.; Groseth, A. High-throughput screening for negative-stranded hemorrhagic fever viruses using reverse genetics. Antivir. Res. 2019, 170, 104569. [CrossRef] [PubMed]

130. Capul, A.A.; de la Torre, J.C. A cell-based luciferase assay amenable to high-throughput screening of inhibitors of arenavirus budding. Virology 2008, 382, 107-114. [CrossRef] [PubMed]

131. Ashburn, T.T.; Thor, K.B. Drug repositioning: Identifying and developing new uses for existing drugs. Nat. Rev. Drug Discov. 2004, 3, 673-683. [CrossRef]

132. Mercorelli, B.; Palu, G.; Loregian, A. Drug Repurposing for Viral Infectious Diseases: How Far Are We? Trends Microbiol. 2018, 26, 865-876. [CrossRef]

133. Pandey, A.; Nikam, A.N.; Shreya, A.B.; Mutalik, S.P.; Gopalan, D.; Kulkarni, S.; Padya, B.S.; Fernandes, G.; Mutalik, S.; Prassl, R. Potential therapeutic targets for combating SARS-CoV-2: Drug repurposing, clinical trials and recent advancements. Life Sci. 2020, 256, 117883. [CrossRef] [PubMed]

134. Madrid, P.B.; Chopra, S.; Manger, I.D.; Gilfillan, L.; Keepers, T.R.; Shurtleff, A.C.; Green, C.E.; Iyer, L.V.; Dilks, H.H.; Davey, R.A.; et al. A systematic screen of FDA-approved drugs for inhibitors of biological threat agents. PLoS ONE 2013, 8, e60579. [CrossRef] 
135. Kim, Y.J.; Cubitt, B.; Chen, E.; Hull, M.V.; Chatterjee, A.K.; Cai, Y.; Kuhn, J.H.; de la Torre, J.C. The ReFRAME library as a comprehensive drug repurposing library to identify mammarenavirus inhibitors. Antivir. Res. 2019, 169, 104558. [CrossRef]

136. Riva, L.; Yuan, S.; Yin, X.; Martin-Sancho, L.; Matsunaga, N.; Pache, L.; Burgstaller-Muehlbacher, S.; De Jesus, P.D.; Teriete, P.; Hull, M.V.; et al. Discovery of SARS-CoV-2 antiviral drugs through large-scale compound repurposing. Nature 2020, 586, 113-119. [CrossRef] [PubMed]

137. Oppliger, J.; Torriani, G.; Herrador, A.; Kunz, S. Lassa Virus Cell Entry via Dystroglycan Involves an Unusual Pathway of Macropinocytosis. J. Virol. 2016, 90, 6412-6429. [CrossRef] [PubMed]

138. Raabe, V.N.; Kann, G.; Ribner, B.S.; Morales, A.; Varkey, J.B.; Mehta, A.K.; Lyon, G.M.; Vanairsdale, S.; Faber, K.; Becker, S.; et al. Favipiravir and Ribavirin Treatment of Epidemiologically Linked Cases of Lassa Fever. Clin. Infect. Dis. 2017, 65, 855-859. [CrossRef]

139. Herring, S.; Oda, J.M.; Wagoner, J.; Kirchmeier, D.; O'Connor, A.; Nelson, E.A.; Huang, Q.; Liang, Y.; DeWald, L.E.; Johansen, L.M.; et al. Inhibition of Arenaviruses by Combinations of Orally Available Approved Drugs. Antimicrob. Agents Chemother. $2021,65$. [CrossRef]

140. Sun, X.; Vilar, S.; Tatonetti, N.P. High-throughput methods for combinatorial drug discovery. Sci. Transl. Med. 2013, 5, 205rv1. [CrossRef] 